\title{
ANALISIS PENERAPAN PROGRAM TAX AMNESTY DI INDONESIA
}

\author{
Valdi Sayoga \\ Program Studi Magister Manajemen Universitas Tarumanagara \\ vs.victory19@gmail.com
}

\begin{abstract}
This study aims to analyze the application of the Tax Amnesty Program and the results generated by the Program to the Level of Taxpayer Compliance, Tax Management, and its Contribution to the Establishment of the Taxation System. The type of research conducted is descriptive qualitative research by collecting materials from the literature, website research and then discussing the Tax Amnesty event based on materials taken from the literature. The results of this study indicate that the Tax Amnesty Program is able to increase Taxpayer Risk Levels, provide taxpayers with ease in their tax matters, but the Tax Amnesty Program does not have a stake in tax management from taxpayers. It is also found that the Tax Amnesty Program has several weaknesses that have been anticipated by other Government Regulations.
\end{abstract}

Abstrak : Penelitian ini bertujuan untuk menganalisis penerapan Program Tax Amnesty dan hasil-hasil yang ditimbulkan atas Program tersebut terhadap Tingkat Kepatuhan Wajib Pajak, Manajemen Pajak, dan Andilnya terhadap Pembentukan Sistem Perpajakan. Jenis penelitian yang dilakukan adalah penelitian kualitatif deskriptif dengan mengumpulkan bahan-bahan dari literatur-literatur, website research lalu melakukan pembahasan terhadap kejadian Tax Amnesty berdasarkan bahan-bahan yang diambil dari literatur-literatur. Hasil dari penelitian ini menunjukkan bahwa Program Tax Amnesty mampu meningkatkan Tingkat Kepatuhan Wajib Pajak, memberi kemudahan bagi Wajib Pajak dalam urusan perpajakannya tapi Program Tax Amnesty tidak memiliki andil dalam Manajemen Pajak yang diselenggarakan oleh Dirjen Pajak kepada Wajib Pajak. Adapula didapatkan bahwa Program Tax Amnesty memiliki kelemahan berupa memberi kesempatan bagi Wajib Pajak yang tidak mengakui penghasilan dan hartanya baik di dalam negeri maupun di luar negeri. Namun dengan Peraturan Pemerintah yang mengikuti pasca Tax Amnesty, kelemahan tersebut mulai teratasi dengan memberikan keadilan bagi Wajib Pajak yang sudah taat dalam urusan perpajakannya.

Kata Kunci : Tax Amnesty, Kepatuhan Wajib Pajak, Manajemen Pajak, Sistem Perpajakan

\section{Latar Belakang}

Pembangunan nasional adalah kegiatan yang berlangsung terus menerus dan berkesinambungan yang bertujuan untuk meningkatkan kesejahteraan rakyat baik materiil maupun spiritual. Pembangunan merupakan tujuan utama setiap negara yang masih berkembang. Setiap negara berkembang pasti ingin membangun sarana prasarana yang dapat mendukung baik kinerja pemerintahan maupun rakyat yang mendiami kekuasaan negaranya. Akan tetapi setiap perkembangan membutuhkan biaya yang tidak sedikit, sehingga negara harus memperoleh dana yang diperlukan tersebut yang tentunya didasari dengan peraturan yang adil dan jelas. Dengan hubungan timbal balik antara Negara dengan masyarakat, dana yang dibayar oleh masyarakat dijadikan pelayanan yang diberikan baik secara langsung maupun tidak langsung. Pembiayaan tersebut berasal dari Pajak.

Pemerintah Indonesia mencoba melihatnya dari sisi investasi yang dilakukan oleh Warga Negara Indonesia ini bahwa Para Pemegang Modal dari Indonesia tidak terlalu tertarik menanamkan uangnya di Indonesia dan seringkali tidak mengakui harta yang dimilikinya. Menurut UU No 11 Tahun 2016, Pengampunan pajak atau Tax Amnesty merupakan penghapusan pajak yang seharusnya terutang, tidak dikenai sanksi administrasi perpajakan 
dan sanksi pidana di bidang perpajakan dengan cara mengungkapkan harta dan membayar uang tebusan.

Tujuan Penelitian adalah menganalisis Penerapan Program Tax Amnesty di Indonesia untuk melihat bagaimana Program Tax Amnesty meningkatkan Kepatuhan Wajib Pajak, mempengaruhi Manajemen Pajak Wajib Pajak, mengetahui perbandingan antara peserta Tax Amnesty dengan yang tidak dan mengetahui Cara Tax Amnesty membentuk sistem perpajakan yang lebih baik. Analisi ini tidak hanya melihat tingkat keberhasilan dari Program Tax Amnesty, tapi juga akan melihat apa yang dapat menyebabkan manajemen perpajakannya menjadi tidak tepat, apa yang mengurangi ketaatan Wajib Pajak dan bagaimana ketidak tepatan tersebut mempengaruhi sebuah laporan keuangan perusahaan. Setelah menelaah penelitian ini, diharapkan pula bagi para pengguna informasi ini bisa mendapatkan referensi mengenai pentingnya ketaatan pajak.

\section{Tinjauan Pustaka}

Pengampunan Pajak merupakan penghapusan pajak yang seharusnya terutang, tidak dikenai sanksi administrasi perpajakan dan sanksi pidana di bidang perpajakan. Kewajiban perpajakan yang mendapatkan Pengampunan Pajak terdiri atas kewajiban Pajak Penghasilan, dan Pajak Pertambahan Nilai atau Pajak Pertambahan Nilai dan Pajak Penjualan atas Barang Mewah. Pengampunan Pajak merupakan terobosan kebijakan yang memiliki manfaat dan tujuan meningkatkan pertumbuhan ekonomi melalui Repatriasi Aset, yang ditandai dengan peningkatan likuiditas domestik, perbaikan nilai tukar rupiah, penurunan Suku Bunga, dan peningkatan investasi, perluasan basis data perpajakan yang lebih valid, komprehensif dan terintegrasi, dan meningkatkan Penerimaan Pajak (https://kemenkeu.go.id/singlepage/amnesti-pajak/)

Djoko Muljono(2009:2) menyatakan bahwa Manajemen Pajak adalah kegiatan menyiasati perpajakan berkaitan erat dengan kegiatan pengusaha yang harus dengan jeli mengamati ketentuan perpajakan yang berlaku serta mengikuti perubahan yang terjadi pada ketentuan tersebut agar dapat memanfaatkan berbagai peluang yang ada, dengan tujuan akhir agar perusahaan dapat membayar pajak dengan benar dan dapat diatur sedemikian rupa sehingga tidak mengganggu kelangsungan perusahaan, terutama yang berkaitan dengan likuiditas dan juga sehemat mungkin. Pemenuhan kewajiban perpajakan dengan benar dan tidak mengganggu kelangsungan perusahaan merupakan tujuan utama perusahaan dalam Manajemen Perpajakan atau dalam menyiasati peraturan perpajakan.

Menurut Kamus Umum Bahasa Indonesia, istilah kepatuhan adalah "Kepatuhan berarti tunduk atau patuh pada ajaran dalam perpajakan kita dapat memberi pengertian bahwa kepatuhan perpajakan merupakan ketaatan, tunduk dan patuh serta melaksanakan ketentuan perpajakan. Jadi, wajib pajak yang patuh adalah wajib pajak yang taat dan mematuhi serta melaksanakan kewajiban perpajakan sesuai ketentuan peraturan perundang-undangan perpajakan."

\section{Metodologi Penelitian}

Penelitian ini merupakan sebuah penelitian deskriptif dengan pendekatan kualitatif yaitu prosedur penelitian dengan mengumpulkan berbagai data dan fakta dari literatur-literatur Peraturan, Teori dan Web Research lalu mengaitkannya dengan kejadian utama yang menjadi pokok bahasan Penelitian ini. Hal tersebut dilakukan untuk mendalami Program Tax Amnesty di Indonesia.

\section{Hasil dan Kesimpulan}

Berdasarkan analisis yang dilakukan dalam penelitian ini menyimpulkan bahwa:

1. Program Tax Amnesty mampu meningkatkan Tingkat Kepatuhan Wajib Pajak karena fasilitas Pengampunan Pajak yang cukup menggiurkan untuk diikuti oleh Wajib Pajak. 
Peningkatan tersebut dapat terjadi berkat fasilitas Program Tax Amnesty untuk menghapuskan Hutang Pajak Tertunggak dan Potensi Pemeriksaan bagi Wajib Pajak yang mau berpartisipasi.

2. Tax Amnesty tidak memiliki andil dalam Aspek Manajemen Pajak dari Wajib Pajak karena Tax Amnesty tidak memperbaiki masih lemahnya pengetahuan Wajib Pajak terhadap Kewajiban Perpajakannya. Hal ini menandakan bimbingan dari Account Representative dan Konsultan Pajak terhadap Wajib Pajak belum maksimal.

3. Peserta Tax Amnesty kebanyakan Wajib Pajak yang kurang patuh tetapi banyak Wajib Pajak yang sebenarnya patuh tetap ikut serta karena tidak adanya jaminan bahwa Wajib Pajak yang patuh aman dari Tindak Pemeriksaan. Hal tersebut disebabkan oleh PMK 74/PMK.03/2012 Tentang Penetapan Wajib Pajak Dengan Kriteria Tertentu yang tidak dapat dijalankan fasilitasnya dengan baik.

4. Program Tax Amnesty membentuk reformasi perpajakan dengan menerapkan Peraturan Pemerintah No 23 Tahun 2018 sebagai kesempatan Wajib Pajak membangun database perpajakannya dari awal.

\section{Daftar Pustaka}

Undang Undang No 11 Tahun 2016 Tentang Pengampunan Pajak https://kemenkeu.go.id/single-page/amnesti-pajak/

https://www.kemenkeu.go.id/publikasi/artikel-dan-opini/tax-amnesty-dan-pengaruhnyaterhadap-tax-compliance/

https://ekonomi.bisnis.com/read/20190318/259/901248/kepatuhan-wp-peserta-tax-amnestybaru-188-persen

https://ekonomi.kompas.com/read/2018/04/01/090000826/sri-mulyani--pelaporan-sptmeningkat-salah-satunya-karena-tax-amnesty

https://www.indonesia-investments.com/id/finance/tax-system/tax-amnestyprogram/item7124?

https://www.pajak.go.id/id/artikel/menakar-kadar-kepatuhan-wajib-pajak

https://money.kompas.com/read/2016/09/19/200000826/ini.keuntungan.dari.mengikuti.tax.a mnesty.?page $=$ all

https://www.kompasiana.com/maimunatuzzahro03/57d27b30529773bc474b4454/pentingnya -mengetahui-manfaat-kelebihan-dan-kekurangan-tax-amnesty 